\title{
DNA and Genealogical Evidence Suggests the Plymouth Colonists were Sephardic Jews
}

\author{
Elizabeth C. Hirschman \\ Hill Richmond Smiddy Professor of Business \\ Department of Business and Economics \\ James A. Vance \\ Associate Professor of Mathematics \\ Department of Mathematics and Computer Science \\ Jesse D. Harris \\ Department of Mathematics and Computer Science \\ The University of Virginia's \\ College at Wise \\ Wise, VA 24293
}

\begin{abstract}
The Plymouth settlement in Massachusetts stands as one of the origin points for American social ideology. The settlers are widely viewed as archetypes of early American culture - British, white and Christian. We challenge this belief using linguistic, genealogical, and DNA evidence. Our research argues that the Plymouth settlers were largely of Sephardic Jewish ancestry, practiced endogamy and engaged in Judaic customs and practices for at least their first two generations in North America. Our findings suggest that colonial American culture was much more diverse in religion and ethnicity than previously believed.
\end{abstract}

Keywords: Plymouth Settlement, Sephardic Jews, DNA genealogy, Colonial American ethnicity, White Nativism.

\section{Introduction}

One of the most iconic images contained in textbooks on early American history is the painting shown below of the Mayflower pilgrims celebrating Thanksgiving with Native American friends in their newly founded colony of Plymouth (www.pro-regforum.com). Although there are several errors in this depiction, for example, the presence of female Native Americans and the leggings worn by the male Native Americans (Philbrick 2006), there is one detail that we will argue is likely an inadvertent insertion by the artist which is actually correct. This is the European man standing at the left rear of the scene, next to the Native and European women talking. He is dressed all in black and is wearing a yarmulke on his head. The yarmulke is worn by observant male Jews (Gwynne 2017). And while we very much doubt that the artist intended this interpretation of the figure he has drawn, we intend to argue that in spirit at least it is appropriate. That is, we propose that the Mayflower pilgrims shown celebrating this 'first Thanksgiving' were Jewish. 


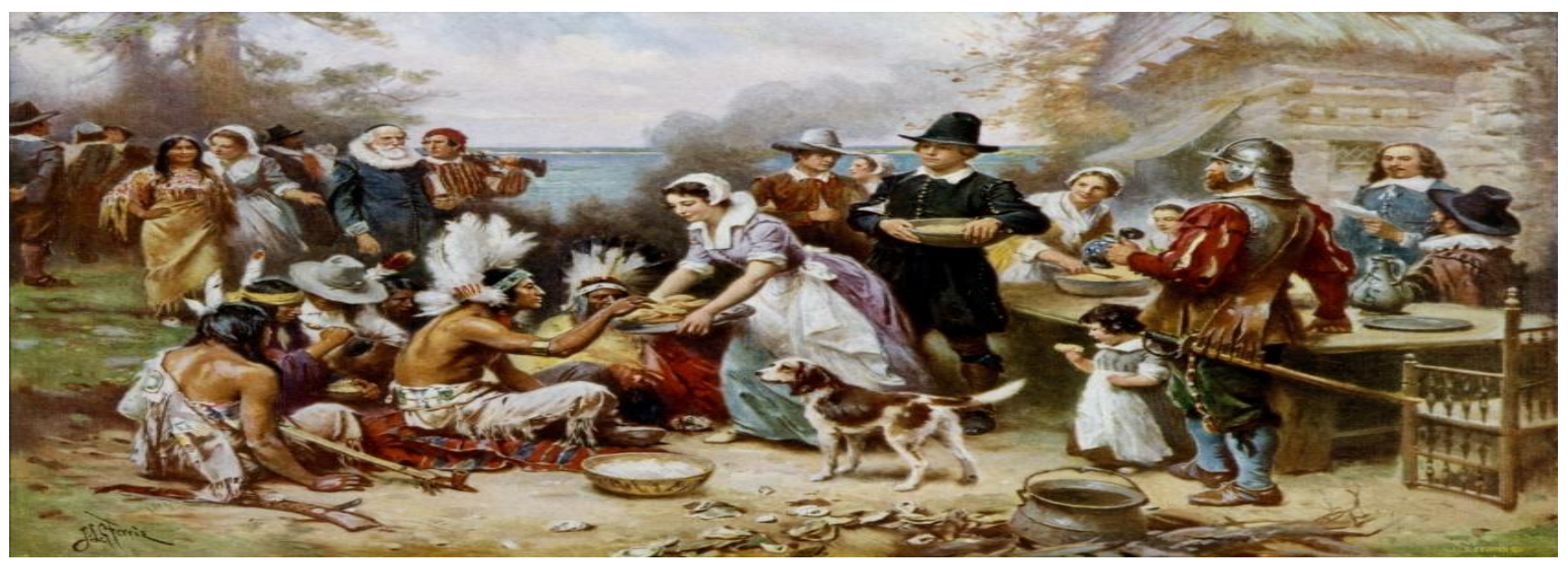

Despite the seeming familiarity of the historic narrative of the Puritan Pilgrims arriving at Plymouth Rock in November 1620 and establishing an English Protestant colony on North American shores, there is much about the actual events that is inconsistent with this traditional story-line (Philbrick 2006). For example, only 50 of the 102 persons landing at Plymouth aboard the Mayflower were actually from the Leiden, Holland congregation of English Puritans. The rest were persons from a variety of backgrounds who took passage on the Mayflower as a way of leaving England and venturing to North America (Bunker 2010). Several were orphaned children who came as wards or servants of these additional passengers, referred to as 'strangers' in the annals written by William Bradford and Edward Winslow (Bradford and Winslow 1622).

Further, the entire set of passengers was contractually bound to work for their sponsor, Thomas Weston, and create a profit-making colony which grew its own agricultural supplies and transported furs back to England (Bunker 2010; Philbrick 2006). Therefore the colony was neither consistently Puritan in its beliefs nor was it specifically established as a religious collective. Third, there were several sailors and soldiers on board, together with three cannons, several muskets and much ammunition and gunpowder (Bunker 2010; Philbrick 2006 ).Thus, the colonists were not assuming they would be arriving in a peaceful locale; indeed they believed the Natives would likely be hostile and that defensive measures would be needed (Bradford and Winslow 1622).

Fourth, despite their commitments to their sponsor, the colonists arrived with little to no farming, fishing or hunting experience (Philbrick 2006). Most had been tradespeople in London and Holland, with the majority employed doing factory work (Bunker 2010). As a result, upon arrival, they had to steal seed corn from Native American caches both to eat that winter and to plant crops the following spring (Bradford and Winslow 1622). Additionally, although the colonists are usually presented as religiously devout Protestants, their regular Leiden pastor, John Robinson, did not accompany them to the New World, and, in fact, there were no ordained ministers among the passengers. Even more unusual was that among the religious literature they brought with them were William Ainsworth's annotated discussions of the first five books of Moses (i.e, the Judaic Pentateuch or Torah) and Ainsworth's accompanying volume translating and discussing the Book of Psalms taken from the original Hebrew (Bunker 2010).

The marital status of the Mayflower passengers and subsequent passengers aboard the Fortune, Little James andAnne is also puzzling. Only 17 of the men arriving were actually married with families. The rest were primarily young, unmarried men (Banks 1929; Philbrick 2006). This also would seem to indicate that the colony was not composed only of religious congregants, but rather of persons seeking to exit Holland and England. We will argue that they were doing so to escape possible attack by Spanish soldiers and also to seek their fortunes in the New World (Bunker 2010). By contrast, virtually all the women and children arriving on the later three ships bound for the Plymouth colony were families of the Puritan congregants (Banks, 1929).

Finally, Banks $(1929$, p. 13) reports that the bulk of the non-Leiden passengers were from an area of London, Aldgate Ward, known for its large "Dutch" colony, which consisted largely of Sephardic Jews who had re-settled in England after first sojourning in the Netherlands and France. Also situated in this same locale was Thomas Weston, who helped finance the voyages to Plymouth through the Merchant Adventurers Corporation (Banks 1929; Bunker 2010). The oldest Jewish synagogue in England, founded just after the formal Restoration of Jews to England in 1655, is located in the same Ward (Philbrick 2006). 
We propose these little examined details should begin to raise some questions about the actual ethnicity and religious identity of the Mayflower passengers. We then couple this with the political knowledge that the Puritan congregants in Holland were under threat from the expiration of a standing treaty between the Low Counties and Spain (Banks 1929; Philbrick 2006). At the time of their departure, the Mayflower passengers feared an attack by Spanish forces similar to those which had occurred in the late 1500s (Bunker 2010). Notably, Leiden was then "teeming with refugees from across Europe" who were fleeing from Spanish insistence on adherence to Catholic orthodoxy (Philbrick 2006, p. 5). Many of these refugees were Sephardic Jews and Muslim Moors who had fled from Spain in the 1500s, converted to Protestantism, and now again feared attack by the Spanish Inquisitors (Bunker 2010; Philbrick 2006).

\section{Indicators of Sephardic Jews among the Plymouth Colonists}

We now turn to examining a variety of indicators suggesting that among the Plymouth Colonists were several Sephardic Jews.

Linguistic Clues: Remarkably, the first clues of non-English ethnicity come directly from the 1622 Mayflower Report written by William Bradford and Edward Winslow, two of the leading members of the Leiden Congregation who arrived on the Mayflower. Throughout their diaries describing the first year in "Plimouth", they use the terms barricado and palizada to describe the fences and fortifications constructed by the Native Americans they encountered (Bradford and Winslow 1622). Since these Native Americans knew no Spanish, the terms were being applied by Bradford and Winslow. One must assume they were familiar with the Spanish language, at least as regards military terminology; we propose this may have resulted from prior encounters with Spanish forces due to their having Spanish Judaic ancestry.

Second, late in life William Bradford taught himself to read Hebrew and even wrote a Hebrew grammar book (Bunker 2010). Historians and Christian religious scholars have attributed this to his desire to purify Protestantism from the doctrinal overlay of the Catholic Church (Bunker 2010). However, this does not seem a tenable explanation. Bradford's focus was upon the Hebrew Pentateuch/Torah, i.e., the first five books of Moses, which he desired to read in their "original language". If Bradford were motivated by Christian curiosity, he would instead have learned Greek which would permit him to access the Christian gospels in their first language of record. A more plausible explanation is that Bradford was of Jewish descent and desired to read the Hebrew Torah in his ancestral tongue, instead of English translations.

Ritual Behavior: Upon first arriving on the shores of Cape Cod, the passengers and crew of the Mayflower came ashore and knelt in prayer (Banks 1929; Bradford and Winslow 1622). This was their original Thanksgiving, and not the meal shared with the Native Americans a year later (Bunker 2010). This religious thanksgiving, as Bunker (2010) notes, was based on Ainsworth's (see Bunker 2010, Chapter 3) discussion of Jewish philosopher Maimonides' commentary on Psalm 107. The giving of thanks to God in Judaism, birkat ha-gomel, is celebrated on four occasions: the healing of a sickness, the release of a prisoner, the end of a voyage, and the arrival of travelers at their destination (Wynne 2017). Thus, the arrival of the pilgrims at Cape Cod would have been an appropriate moment to give thanks, and they did so by reciting Psalm 107.

Psalm 107Give thanks to the LORD, for he is good; his love endures forever.

Let the redeemed of the LORD tell their story-those he redeemed from the hand of the foe, those he gathered from the lands, from east and west, from north and south.

Some wandered in desert wastelands, finding no way to a city where they could settle.

They were hungry and thirsty, and their lives ebbed away.

Then they cried out to the LORD in their trouble, and he delivered them from their distress.

He led them by a straight way to a city where they could settle.

Let them give thanks to the LORD for his unfailing love and his wonderful deeds for mankind, for he satisfies the thirsty and fills the hungry with good things.

William Bradford, who later became Governor of the colony, described their arrival at Plymouth as follows (Bradford and Winslow 1622):

"Thus out of small beginnings greater things have been produced by His hand that made all things of nothing, and gives being to all things that are; and as one small candle may light a thousand, so the light here kindled hath shone unto many, yea in some sort to our whole nation; let the glorious name of Jehova have all the praise." 
On Bradford's tombstone is written in Hebrew "Jehova is our help" and below it in Latin "What our fathers with so much difficulty secured, do not basely relinquish" (see Bunker 2010).

Thus, the use of appropriate Jewish prayers, the return to the Hebrew language and the calling upon Jehova, rather than Christ or Jesus, would seem strong indicators that the religion of the colony was Judaism, and not Protestant Christianity.

Naming Patterns: Names given to the first two generations of children born to the Plymouth Colony settlers displayed some distinctly Judaic, Greek and Latin origins. These are listed in Table One below. Several of the Jewish names are 'common', such as Martha, David, Sarah, Hannah and Ruth, and therefore are not necessarily diagnostic of our hypothesis. However, others are quite rare and require a deep knowledge of Hebrew; these are almost exclusively used by Jews. They include Bethia, Benoni, Elkanah, Ebenezer, Shubael, Jabez, Mehetebal, and Jael.

Further, the Latin Sylvanus means 'forest' or 'woods' and was a common given name among Sephardic Jews (www.sephardim.com). Similarly Theophilus is Greek meaning 'one who loves God' and was rarely used among English citizens of the time period. Jews, however, did use Theophilus as a given name drawing on the Theophilus who was a high priest of the Second Temple period in Israel (Wynne 2017). Similarly, the name Damaris is a Jewish Greek name dating from the Second Temple period when Greek was the principal language spoken in Israel (Wynne 2017). Finally, the given name Alexander dates from the same epoch in Jewish history i.e., after the conquest of Israel by Alexander the Great and the subsequent Grecian influence on Judaic customs and language (Wynne 2017). The presence of these names in the set of given names by the early Plymouth colonists is strong evidence of their ancestral origins as Jews. It does not support the accepted notion that these were simply 'biblical' names chosen by devout Protestants.

\section{Table One}

\section{Naming Patterns of the Mayflower Settlers}

$\begin{array}{lll}\text { Martha } & \text { Ellis } & \text { Lorah } \\ \text { Aaron } & \text { Ephraim } & \text { Lydia } \\ \text { Abigail } & \text { Esther } & \text { Mehitable } \\ \text { Adam } & \text { Ezekiel } & \text { Melatia } \\ \text { Alexander } & \text { Hannah } & \text { Moses } \\ \text { Bartholomew } & \text { Hezekiah } & \text { Nathaniel } \\ \text { Benjamin } & \text { Ichabod } & \text { Rachel } \\ \text { Benoni } & \text { Isaac } & \text { Rebecca } \\ \text { Bethiah } & \text { Israel } & \text { Ruth } \\ \text { Caleb } & \text { Jabez } & \text { Samuel } \\ \text { Damaris } & \text { Jacob } & \text { Sarah } \\ \text { Daniel } & \text { Jael } & \text { Seth } \\ \text { David } & \text { Jonathan } & \text { Shubael } \\ \text { Deborah } & \text { Joseph } & \text { Solomon } \\ \text { Dorcas } & \text { Joshua } & \text { Sylvanus } \\ \text { Elisha } & \text { Josiah } & \text { Theophilus } \\ \text { Elkanah } & \text { Judah } & \text { Zachariah }\end{array}$

\section{Names Found Among the Early Plymouth Settlers' Spouses:}

Equally of interest for our thesis are the names, both given and surnames, of those persons whom the Plymouth Colony settlers married during the first two generations.

As can be seen in Table Two below, there is strong evidence of their marrying persons with specifically Hebrew given names and Jewish surnames. Take note of given names such as Judah, Hepzibah, Moses, Bathsheba, Ephraim, Eleazar, Naomi and Esther. These refer to specifically Hebrew persons celebrated for their contributions to Jewish history (Wynne 2017). They were almost exclusively used by Jews during this time period, just as they are now. A particularly diagnostic name appearing in the list is Persis, which means a 'woman from Persia' and refers to the Jews taken to Babylonia under Nebuchadnezzar and then permitted to return to Israel by Cyrus the Great (598 - 586 BCE). 
The surnames of marriage partners are also very suggestive of Jewish ethnicity. For example, several are of French derivation, which was common among Sephardic Jews who had migrated to France in the early 1500s, after being expelled during the Spanish Inquisition (Benbassa and Rodrique 2000). Bonney, for example, could have originally been Bueno (Good) in Spanish and translated as Bonne in French. Cushman is typically a Jewish surname, as are Freeman and Goodman. LeBlond in French would be Blanc/White in Spanish, Burroughs was a common transliteration of the Jewish surname Baruch (Blessed) in Hebrew, Starr would be Stern in German/Dutch, another common Jewish surname. Fobes is the Greek Phoebus, also common among Jews of the time, Snell is German for Fast/Swift, Adams is straightforwardly Hebrew, Morey would be equivalent to Muslim/Moor, and Savill is straightforwardly a Spanish place name, Seville, just as Steele is a shortened form of Castille. There are several names such as King, Pope, and Prince which were given to Jews in service to persons holding these positions. In this same line of reasoning we find the name of Mayflower's captain, Coppin, which is a medieval version of Jacob. Taber, after Mount Tabor, is a Jewish surname, and Chandler is a trade name meaning merchant, a common Jewish occupation at the time.

\section{Table Two}

\section{Given and Surnames Of Plymouth Colony Settlers Marriage Partners:First Two Generations}

\section{Given Names:}

Surnames:

$\begin{array}{lll}\text { Abigail } & \text { Hosea } & \text { Moses } \\ \text { Abraham } & \text { Ichabod } & \text { Naomi } \\ \text { Alexander } & \text { Isaac } & \text { Nathan } \\ \text { Bathsheba } & \text { Isabella } & \text { Nathaniel } \\ \text { Benjamin } & \text { Israel } & \text { Obadiah } \\ \text { Bethiah } & \text { Jeremiah } & \text { Penelope } \\ \text { Caleb } & \text { Jonathan } & \text { Persis } \\ \text { Daniel } & \text { Joseph } & \text { Phebe } \\ \text { Deborah } & \text { Joshua } & \text { Puella } \\ \text { Ebenezer } & \text { Josiah } & \text { Rachel } \\ \text { Eleazar } & \text { Judah } & \text { Rebecca } \\ \text { Elkanah } & \text { Judith } & \text { Ruth } \\ \text { Ephraim } & \text { Judith } & \text { Samuel } \\ \text { Esther } & \text { Lucretia } & \text { Shubael } \\ \text { Giles } & \text { Lydia } & \text { Simon } \\ \text { Hannah } & \text { Martha } & \text { Tobias } \\ \text { Hepzibah } & \text { Mehitabel } & \text { Uriah } \\ \text { Hester } & \text { Meribah } & \end{array}$

$\begin{array}{lllll}\text { Adams } & \text { Chaffin } & \text { Goodman } & \text { Morse } & \text { Snell } \\ \text { Barnaby } & \text { Chandler } & \text { Green } & \text { Mountjoy } & \text { Snow } \\ \text { Barrows } & \text { Copeland } & \text { Grinnell } & \text { Oakman } & \text { Soule } \\ \text { Bartlett } & \text { Cushman } & \text { Hallet } & \text { Pabodie } & \text { Spraque } \\ \text { Beal } & \text { Dart } & \text { Hussey } & \text { Pope } & \text { Starr } \\ \text { Beman } & \text { Davoll } & \text { Joyce } & \text { Pratt } & \text { Steele } \\ \text { Bennett } & \text { Delano } & \text { King } & \text { Prence } & \text { Sturgis } \\ \text { Blossom } & \text { Dimock } & \text { LeBlond } & \text { Price } & \text { Sturtevant } \\ \text { Bompasse } & \text { Doty } & \text { Lewis } & \text { Ring } & \text { Taber } \\ \text { Bonham } & \text { Dutch } & \text { Lombard } & \text { Sabin } & \text { Vassal } \\ \text { Bonney } & \text { Eddy } & \text { Lovell } & \text { Sampson } & \text { Vermayes } \\ \text { Brooks } & \text { Ellis } & \text { Martin } & \text { Savill } & \text { Viall } \\ \text { Brownell } & \text { England } & \text { Mayo } & \text { Shove } & \text { Walden } \\ \text { Burrill } & \text { Fobes } & \text { Mendall } & \text { Shurtleff } & \text { Waterman } \\ \text { Burroughs } & \text { Freeman } & \text { Merrick } & \text { Simmons } & \text { Wilder } \\ \text { Burrows } & \text { Glass } & \text { Morey } & \text { Skiff } & \end{array}$

The Frequency and Intensity of Endogamy: 
The Plymouth colony was notable also for its remarkable level of endogamy within the first two generations (Bureau of Military and Civic Achievement, 1922). Endogamy refers to the tendency to marry 'within the group' and was found primarily among Jews and Muslims during the time period under consideration. We propose that the members of the Plymouth colony who engaged in endogamy were Sephardic Jews and purposely did so to maintain their religious unity. Table Three below lists the families practicing endogamy and the families they intermarried with across the first two generations.

\section{Table Three}

\section{List of Endogamous Families in First Two Generations of Plymouth Settlers}

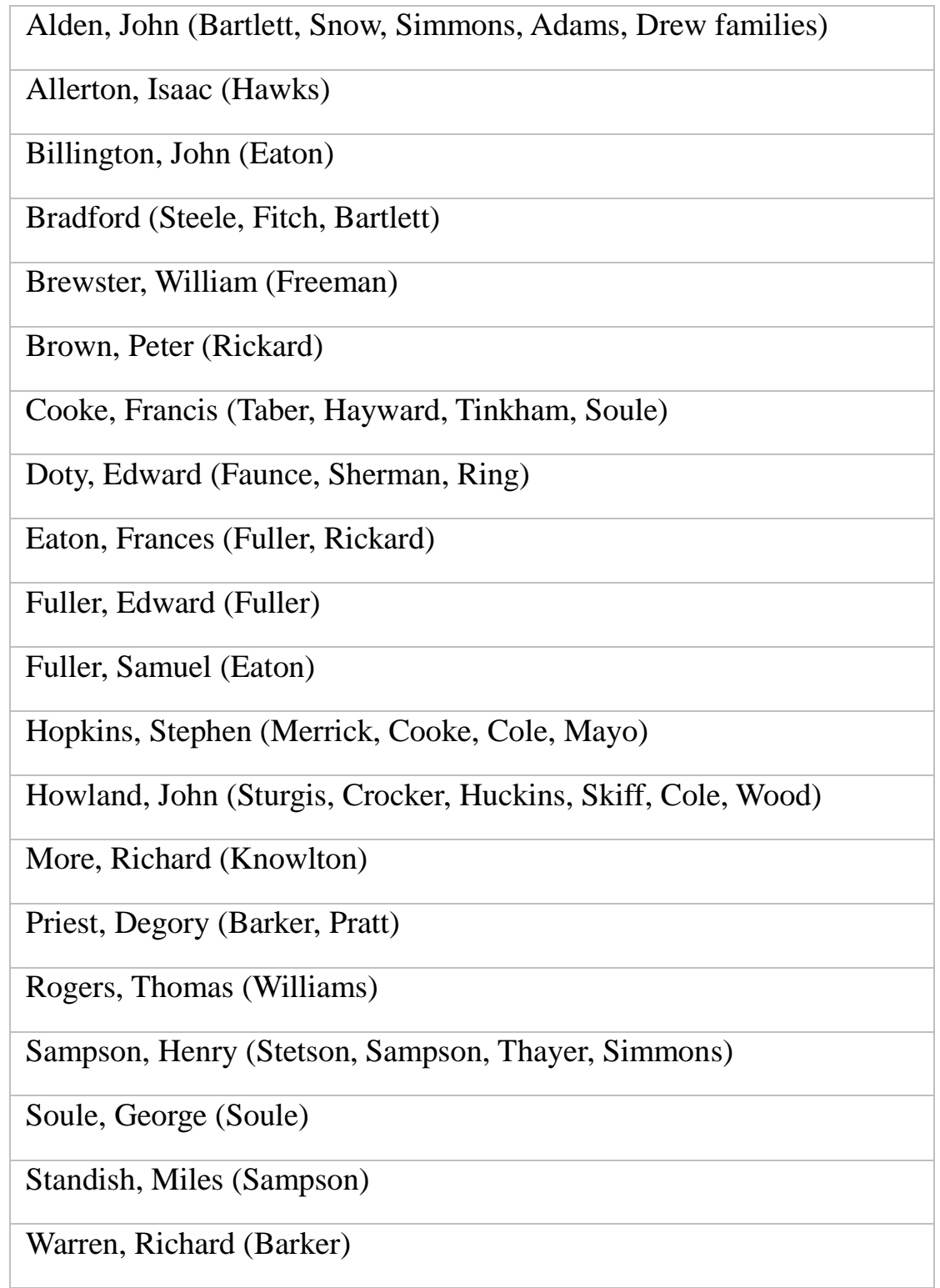

As is indicated in the above listing, some families married first cousins and by the third generation, virtually all were marrying second cousins on a repetitive basis (Bureau of Military and Civic Achievement 1922). Such a pattern would have resulted in a highly condensed genetic ancestry pool, a subject to which we now turn.

\section{Dna Testing of The Plymouth Colonists}

Perhaps one of the greatest scientific tools now available to social scientists investigating race, ethnicity and religion is the possibility of tracing ancestral lineage through DNA. The successful mapping of the human genome in 2000 (National Geographic DNA Project 2006) made available for the first time the opportunity to accurately trace patterns of human migration and descent, not only for groups, but also for specific individuals. 
We now have learned, for example, that approximately $8 \%$ of all persons now living in the former Mongol Empire are descended from Genghis Khan and his four sons (www.nationalgeographic.com).

In 2006, the National Geographic Society completed the first global mapping of human haplotypes, compiling a data base of over 850,000 individual samples from across the globe (National Geographic Society, 2006). At present, academic and commercial enterprises have greatly expanded the mapping of human origins - to the extent that virtually every ethnic group, religious group, nationality and indigenous tribe has been tested and the results uploaded onto publicly-accessible websites (see e.g., Fadlouhi-Zid 2015).

In the present study, we utilize a database containing both female (MtDNA) and male (Y chromosome) DNA samples. These two types of DNA ancestry testing are described below.

\section{FEMALE AND MALE ANCESTRY TESTING}

\section{Mitochondrial DNA (MtDNA) testing:}

Mitochondrial DNA is transmitted from mother to child, so that a direct maternal ancestor can be traced using mtDNA. A perfect match found to another person's mtDNA test results indicates shared ancestry of possibly between 1 and 50 generations ago.

More distant matching to a specific haplogroup or subclade may be linked to a common geographic origin (Lewis 2011). In the present study, we trace female ancestry to the regional and national level, e.g., Iran, the Middle East.

MtDNA is divided into three regions. They are the coding region (00577-16023) and two Hyper-variable Regions HVR1 [16024-16569] and HVR2 [00001-00576]. The most common mtDNA tests are a sequence of HVR1 and HVR2 and a full sequence of the mitochondria. This type of testing was used in the present study (Lewis 2011).

\section{Y chromosome (Y-DNA) testing:}

The Y-Chromosome is one of the 23 pairs of human chromosomes. Only males have a Y-chromosome, since women have two $\mathrm{X}$ chromosomes in their 23rd pair. A man's paternal ancestry can be traced, because the Ychromosome is transmitted from father to son nearly unchanged (Lewish 2011).A man's test results are compared to another man's results to determine the time frame in which the two individuals shared a most recent common ancestor in their direct paternal line. A woman who desires to know her paternal ancestry can ask her father, brother, paternal uncle, paternal grandfather, or a paternal uncle's son to take a test for them (Lewis 2011). There are two types of male DNA testing: STRs and SNPs.

\section{STR markers}

The most common type of male ancestry testing is done with what are called STR's or Short Tandem Repeats (Lewis 2011). These are pairings of genetic coding material which are passed from father to son. The more STR markers tested, the more accurate the results will be in determining paternal lineage. In the present study, comparisons with as many as 25 STR markers are used, which provides a high degree of accuracy. The results of two individuals are compared to see how closely they correspond (Lewis 2011).

Current research suggests that all contemporary human men descend in the paternal line from a single African man, who lived probably around 135,00 years ago (Lewis 2011). Different branches of this lineage are termed haplogroups (Lewis 2011). Most haplogroups can be further subdivided into what are called sub-clades. In the present study, we will document the presence of some subclades among the Plymouth settler sample which are important for our thesis. Maps of the global distribution of the female and male ancestries relevant to our study are given in the Appendix.

Fortunately, because of the significance of the Plymouth colony for American history, descendants of these original settlers have carefully documented their genealogy. With the advent of publicly available DNA testing, members of the Mayflower Society, the group to which descendants belong participated in a DNA Project with Family Tree DNA, the world's largest DNA testing firm (www.ftdna.com/MayflowerProject). The results of the testing are now publicly available on-line. Tables Four and Five display the haplogroups to which the male and female Mayflower and Plymouth colonists belong. For each colonist listed, there are also specific haplotype profiles available which may be entered into global DNA databases to determine what other persons share the same genetic ancestry. Here is what was learned about the genetic origins of the Plymouth settlers.

\section{Male Founder Lines:}

Due to the few male survivors among the early colonists, there are only 16 men whose descendants were available for testing (www.familytreedna.com/MayflowerProject). As seen in Table One below, among these 16 lineages, 
the majority were in the R-m269 haplogroup (i.e., Alden, Billington, Doty, Eaton, Fuller, Hopkins, Howland, Rogers and White). R-m269 is the most common male haplogroup in Europe, making it difficult to determine ethnic origin. However, there is a Jewish DNA Project which contains the haplotypes of R-m269 persons with known Jewish ancestry (www.ftdnaR1bJewishProject). The haplotypes of the 10 Plymouth R-m269 colonists were checked against this database and nine were found to match persons in it. While not diagnostic with certainty, this suggests that these Plymouth men came from Jewish ancestral lines.

Table One

Y Dna Haplogroups for the Plymouth Colony Settlers

\begin{tabular}{|l|l|l|l|}
\hline Alden, John & R-m269 & Hopkins, Stephen & R-m269 \\
\hline Billington, John & R-m269 & Howland, John & R-m269 \\
\hline Bradford, William & I-m253 & Rogers, Thomas & R-m269 \\
\hline Brewster, William & I-m253 & Sampson, Henry & I-m223 \\
\hline Doty, Edward & R-m269 & Soule, George & I-m253 \\
\hline Eaton, Frances & R-m269 & Standish, Miles & I-m176 \\
\hline Fuller, Edward & R-m269 & White, William & R-m269 \\
\hline Fuller, Samuel & R-m269 & Winslow, Edward & I-m253 \\
\hline
\end{tabular}

George Soule, William Brewster, William Bradford and Edward Winslow were all in the I-m253 haplogroup. This haplogroup has its highest level of concentration in southeastern Europe, especially in Croatia, the Balkans and Slovenia, as well as in the Scandinavian countries and Northeastern European countries such as Czechoslovakia (www.worldfamilies.net/yhaplogroups). Thus it was anticipated that both Sephardic and Ashkenazic Jewish matches might be found for these four men. Using Y-Search, an international database of male DNA haplotypes, we found the following matches.

\section{Brewster:}

Arnold

Blackman (England)

Brewster

Daniels (Russia)

Deutsch (Germany)

Doak (Ireland)

Fletcher

Gonzalez (Puerto Rico)

Gorshkov (Russia)

Hull (England)

Isaacs

Jablonowski

Jardine

Lyons

Moore

Piasetzski (France)

Po (Sweden)

Rhoades

Roman (Germany)
$22 / 25$

$21 / 25$

25/25 for 9 persons named Brewster, most reside in Virginia

$21 / 25$

$21 / 25$

$22 / 25$

$23 / 25$

$21 / 25$

$21 / 25$

$22 / 25$

20/25, 20/25 (England)

$22 / 25$

$21 / 25$

$21 / 25$

$25 / 25$

$21 / 25$

$22 / 25$

$21 / 25$

$21 / 25$

As can be seen above, the William Brewster haplotype matches were confirmed as valid by the several matches to other Brewsters now living in the United States. Notably, there was also a 25/25 marker match to the Moore surname, which historically was used to refer to Moors and/or Sephardic Jews (see Sephardim.com). But most 
indicative of Brewster's likely Sephardic Jewish ancestry are the close matches to names such as Fletcher ("Flesher/Butcher" in German), Jardine (a French Sephardic Jewish surname), Rhoades, for the island of Rhodes where there was a large Sephardic Jewish population, Lyons, for Lyon, France which had a Sephardic Jewish population, Deutsch (a common Ashkenazic Jewish surname), Gonzalez in Puerto Rico is a common Sephardic surname, and finally Isaacs, which is a Jewish surname (see Benbassa and Rodrique 2000). Thus we believe a strong case can be made that Brewster of the Plymouth colony was of Jewish ancestry.

\section{Soule:}

$\begin{array}{ll}\text { Alaimo (Italy) } & 23 / 25 \\ \text { Brazel } & 22 / 25 \\ \text { Chevalley (Switzerland) } & 22 / 25 \\ \text { Cossel } & 22 / 25 \\ \text { Daniel } & 22 / 25 \\ \text { Dantas (Denmark) } & 22 / 25 \\ \text { Davis } & 24 / 25 \\ \text { Fox } & 25 / 25 \\ \text { Gardner } & 22 / 25 \\ \text { Gordon } & 22 / 25 \text { (many) } \\ \text { Kealkee } & 22 / 25 \\ \text { Key } & 22 / 25 \text { (many) } \\ \text { Kuklo (Poland) } & 22 / 25 \\ \text { Moller (Germany) } & 22 / 25 \\ \text { Parrott } & 22 / 25 \\ \text { Perry } & 22 / 25 \\ \text { Pollock (Scotland) } & 22 / 25 \\ \text { Rasmussen (Denmark) } & 22 / 25 \\ \text { Sanders } & 22 / 25 \\ \text { Simonsen (Denmark) } & 22 / 25 \\ \text { Smeltzer } & 22 / 25 \\ \text { Soles/Soule } & 25 / 25 \text { (n=9) } \\ \text { Van Pelt (Belgium) } & 22 / 25 \\ \text { Veldsman (Germany) } & 23 / 25 \\ \text { Zenter (Germany) } & 22 / 25\end{array}$

The DNA matches for George Soule also displayed a Judaic pattern. We deem the haplotype used to be correct, as it matched several other Soles/Soule persons. This haplotype was also an exact or very close match to the surnames Fox and Davis, both common Jewish surnames, see. e.g., (www.jewfaq.org/jnames.htm). There were many matches to persons surnamed Gordon, a common surname among Russian Jews (www.jewfaq.org/jnames.htm). Other surnames indicate that the Soule haplotype is carried by Ashkenazi Jews, e.g., Smeltzer, Simonsen, Cossel, Zentner, Veldsman. There is also indication that this haplotype is found among Sephardic Jews, for example the surnames Perry, Parrott, Brazel, Alaimo (see www.sephardim.com). Thus,we believe that it is likely that George Soule's ancestors were Jewish.

\section{William Bradford:}

$\begin{array}{ll}\text { Bradford } & 24 / 25,23 / 25 \text { several } \\ \text { Brown (Sweden) } & 23 / 25 \\ \text { Hansen (Norway) } & 22 / 25 \\ \text { Holland } & 22 / 25 \\ \text { Kihlman (Sweden) } & 23 / 25 \\ \text { Moller (Germany) } & 22 / 25 \\ \text { Olson (Sweden) } & 23 / 25 \\ \text { Schruyer } & 22 / 25 \\ \text { Seatree (England) } & 23 / 25\end{array}$

As the haplotype match pattern above indicates, the Bradford haplotype we used is valid, for it matches other Bradfords. However, importantly, it does not make a strong case for William Bradford having Jewish ancestry. 
Indeed, most of the Bradford matches are to persons living in Scandinavia, especially Sweden, and the British Isles. A weaker argument can be made that although the Bradford haplotype was originally Scandinavian, perhaps some persons converted to Judaism during the Middle Ages. Support for this possibility comes from the matches to Kihlman and Brown (from Sweden) and the matches to Holland (a common surname of Sephardic emigres (www.sephardim.com)).

Digging deeper to follow this thread of reasoning, we found that the surnames Kihl/Kiehl and Kihlman/Keihlman are, often Jewish and found in both Finland and Russia. The name derives from the low Middle German word for 'wedge'/kil. For example, Kiehl's cosmetic company in America was founded by Russian Jews (www.Kiehls.com). The surname Bradford, itself, is likely to have originated not as an ethnic name, but rather as an English place name, as in Broad Ford. So we will view William Bradford as a person having possible Jewish ancestry, given his DNA. Certainly his embracing of the Hebrew language and practices are stronger indicators.

\section{Edward Winslow}

$\begin{array}{lllr}\text { Edward Winslow: Aaron } & & & \\ \text { Luxembourg } & 28 / 31 & \text { Komarov Russia } & 32 / 37 \\ \text { Blohin Russia } & 28 / 32 & \text { Kudin } & 32 / 37 \\ \text { Buda Italy } & 26 / 31 & \text { Moseley } & 29 / 32 \\ \text { Burrell } & 34 / 37 & \text { Moses } & 33 / 37 \\ \text { Chrenka Czechoslovakia } & 32 / 37 \text { (many) } & \text { Ostrander } & 32 / 37 \\ \text { Coryell } & 33 / 35 & \text { Renouf Channel Islands } & 33 / 37 \\ \text { Dostal Czechoslovakia } & 27 / 29 \text { (many) } & \text { Shiver } & 32 / 37 \\ \text { Ellis } & 32 / 37 & \text { Shtrunov Russia } & 30 / 32 \\ \text { Harder Germany } & 32 / 37 & \text { Simmons, Leiden, Holland } & 35 / 37 \\ \text { Harris } & 32 / 37 & & \end{array}$

Edward Winslow was the co-author, with William Bradford of the 1622 Mayflower Report. There is only one Winslow haplotype given by the Mayflower Society and the Mayflower DNA Project. When this 37 marker haplotype was input to the Y-Search data-base, a 35/37 match was found to a man surnamed Simmons (Jewish surname) from Leiden, Holland - the very city in which the Mayflower pilgrims were congregating (Philbrick 2006). A $35 / 37$ marker match has a $99 \%$ probability of indicating lineal ancestry over a 500 year period. Thus, other close matches were found to persons named Burrell, Coryell, Shtrunov (Russia), Renouf (Channel Islands), Dostal (several in Czechoslovakia), Chrenka (several in Czechoslovakia),Moses, Mosely and Aaron. Checking the ethnicity of both the Dostal and Chrenka surnames indicated that several persons with this surname were of Ashkenazic Jewish ancestry. The surnames Moses and Aaron are straightforwardly Hebrew. Thus, we believe that a presumptive case can be made that Edward Winslow was Jewish. We believe it is also likely that his ancestral name was Simmons, and that he, or his parents/grandparents, may have adopted a more English-sounding name, as did many Jews during the time period, to avoid entanglements with the Inquisition (Benbassa and Rodrique 2000).

\section{MALE HAPLOGROUOP I-m436}

Miles Standish, Henry Sampson and Francis Cooke all carry haplotypes belonging to haplogroup I-m436, which is most common in southeastern Europe, Sardinia and the Basque region of Spain. These are areas where one might expect to find Ashkenazic and/or Sephardic Jewish ancestry, and when the haplotypes of these three men were input to Y-Search, the following results were found :

\section{Miles Standish:}

$\begin{array}{ll}\text { Berry } & 25 / 25 \\ \text { Bridely } & 24 / 25 \\ \text { Cotton (Puerto Rico) } & 23 / 25 \\ \text { Garrison } & 21 / 25 \\ \text { Hart } & 25 / 25,24 / 24 \\ \text { Jung (Switzerland) } & 20 / 25 \\ \text { Levack } & 23 / 25 \\ \text { Nikonov (Russia) } & 20 / 25\end{array}$




$\begin{array}{ll}\text { Parmenter } & 21 / 25 \\ \text { Reynaud } & 23 / 25 \\ \text { Standish } & 25 / 25 \\ \text { Stanley } & 25 / 25 \\ \text { Van Dyke } & 21 / 25\end{array}$

Miles Standish had a rare DNA haplotype, but his matches are very informative. First, the haplotype we used does match other Standish surnames in the Y-search database, so it is deemed valid. The close matches to persons surnamed Berry, Hart and Levack are indicators of Ashkenazic Jewish ancestry and the close match to Cotton in Puerto Rico suggests possible Sephardic Jewish ancestry, as well. The surname Parmenter is of French origin, meaning one who adorns garments, and is also often Jewish (www.avotaynu.com). Thus, we believe a strong case can be made for Miles Standish having Jewish ancestry.

Francis Cooke:

$\begin{array}{ll}\text { Alfeld } & 21 / 25 \\ \text { Blake (England) } & 22 / 25 \\ \text { Brown } & 22 / 25 \\ \text { Chandler (England) } & 22 / 25,21 / 25,20 / 25 \\ \text { Daniels } & 25 / 25 \\ \text { Dias } & 20 / 25 \\ \text { Gammage } & 20 / 25 \\ \text { Jacobsen (Denmark) } & 21 / 25,21 / 25 \\ \text { Kinney/Kinne/Kenney } & 20 / 25 \text { several } \\ \text { Koch (Germany) } & 20 / 25 \\ \text { Metz (Germany) } & 22 / 25 \\ \text { Zeinstra (Netherlands) } & 20 / 25\end{array}$

The Francis Cooke haplotype was also very rare and, although it was the only one listed on the Mayflower Society database, did not have any matches to other Cookes/Cooks. However, it did have a 20/25 match to a German haplotype surname Koch, which means Cook. The haplotype was an exact match to the surname Daniels, which is Hebrew. It had close matches to persons named Brown and Blake/Black, implying possible dark complexions. The several English Chandler matches are also supportive of Jewish ancestry, as Chandler means 'merchant'. The matches to Jacobsen in Denmark suggest Jewish ancestry. Finally, the match to Dias, a Portuguese Sephardic surname, also suggests Jewish ancestry (www.sephardim.com). Thus, we propose that Francis Cooke was Jewish by descent.

\section{Henry Sampson:}

$\begin{array}{llll}\text { Alsop (England) } & 23 / 25 & \text { Martin } & 23 / 25 \\ \text { Bass } & 24 / 25 & \text { Martin/Yoder/Zimmerman modal } & 23 / 25 \\ \text { Chandler (England) } & 23 / 25 & \text { Murray (England) } & 24 / 25 \\ \text { Cone } & 24 / 25,24 / 25 & \text { Rice (England) } & 23 / 825 \\ \text { DeRosiers } & 23 / 25 & \text { Rinehart } & 22 / 25 \\ \text { Friedman } & 23 / 25 & \text { Samson/Sampson } & 25 / 25 \text { (many) } \\ \text { Galarza (Spain) } & 22 / 25 & \text { Silva } & 22 / 25 \\ \text { Harrison } & 24 / 25,23 / 25 \text { several } & \text { VanDijk } & 24 / 25 \\ \text { Kaufmann (Germany) } & 21 / 25 & \text { Wolfe (Germany) } & 22 / 25 \\ \text { Kilmas (Poland) } & 23 / 25 & & \end{array}$

Henry Sampson's DNA haplotype turned out to be very widely distributed, but the matches are quite informative. First, there were several matches to other persons surnamed Sampson at the 25/25 level, thus we conclude the sample we have is valid. The primary matches were to persons surnamed Van Dijk (i.e., a Dutch place name), Cone (Cohen is a Jewish ancestral name) and Bass, a common Sephardic surname meaning short/low (www.Sephardim.com). There were other matches to persons surnamed Mosher, Folkman, Lehman, Braun, Hamar, Kopp, Spiers, Ortiz, Goldsmith and so forth. This would seem to support the presumption of a Jewish ancestral haplotype that is currently found in Eastern Europe, Western Europe, Italy, and the New World. Thus, we conclude that, as his surname implies, Henry Sampson was likely of Jewish ancestry. 


\section{Female Founder Dna:}

Female Founder Lines: The composition of the female founder lines among the Plymouth settlers was remarkable. While most of the DNA haplotypes of the male lines suggest Jewish ancestry, the female lines render this hypothesis largely confirmed. The largest number of female Plymouth settler haplotypes were drawn from haplogroups H (undifferentiated) (32), I (13), T2 (21), K,1,2 (14) J,1,2 (24), all of which are centered in the Middle East and Iran. The sole exception is 21 haplotypes belonging to haplogroup U5 which is most common in Estonia, Finland and among the Saami. We interpret this latter group as also providing conditional support for the Jewish ancestry hypothesis, because Ashkenazi Jews also exhibit the $U$ haplogroup, as shown in the Table Four below. What this pattern suggests is that the female lines among the Plymouth settlers were composed of a variety of female Jewish ancestries ranging from Sephardic and Ashkenazic sources to Persian/Iranian Sources.

The presence of women whose Jewish ancestries originate in Persia would also account for the use of the name Persis, found within the first two generations of Plymouth colonists.

Table Four

Mtdna of the Plymouth Colony Settlers

$\begin{array}{ll}\text { H (undifferentiated) Palestinians, Syrians, Druze, Iraqis } & 32 \\ \text { H1 A1 Basques, Maghreb, Andalusia } & 1 \\ \text { H1J Basque } & 1 \\ \text { H3 Portugal, Spain, Sardinia, Finland } & 10 \\ \text { H4A1 A Iberia } & 5 \\ \text { H5A1 West Caucasus } & 8 \\ \text { H6 Central Asia } & 1 \\ \text { H7 Europe, West Asia } & 3 \\ \text { HV West Asia, Southern Europe } & 6 \\ \text { I, I1, I2, I3 Iran } & 13 \\ \text { J Middle East } & 9 \\ \text { J1 Saudis, Iraqis, Palestinians } & 13 \\ \text { J2 Jewish } & 2 \\ \text { K,1, 2 Druze, Palestinians, Kurdistan } & 14 \\ \text { T1 Iranian } & 7 \\ \text { T2 Saudi Arabia, Iranian } & 21 \\ \text { U Eastern Europe, Anatolia } & 1 \\ \text { U2 South Asia } & 3 \\ \text { U3 Middle East } & 1 \\ \text { U4 Scandinavia, Baltic } & 7 \\ \text { U5 Estonia, Finland, Saami } & 21 \\ \text { W, 1, 3, 5 North Pakistan, Algeria } & 5\end{array}$

\begin{tabular}{|c|c|c|c|c|c|c|c|}
\hline \multirow[b]{3}{*}{ Haplogroup } & \multicolumn{7}{|c|}{ Ashkenazi Jewish Maternal Lineages } \\
\hline & Un-planned & Poland & & Roman & AshJ & $R U$ AshJ & \\
\hline & Test & $\mathrm{N}=192$ & $\%$ & $\mathrm{~N}=104$ & $\%$ & $\mathrm{~N}=150$ & $\%$ \\
\hline $\mathrm{U}($ non-K) & $\mathrm{a}$ & 12 & 6.3 & 5 & 4.8 & 11 & 7.3 \\
\hline $\mathrm{K}$ & $\mathrm{c}$ & 72 & 37.5 & 32 & 30.8 & 25 & 16.7 \\
\hline $\mathrm{HV}^{*}$ & a & 20 & 10.4 & 8 & 7.7 & 19 & 12.7 \\
\hline $\mathrm{H}$ & $\mathrm{b}$ & 27 & 14.1 & 27 & 26 & 41 & 27.3 \\
\hline $\mathrm{J}$ & $\mathrm{a}$ & 18 & 9.4 & 9 & 8.7 & 15 & 10 \\
\hline $\mathrm{T}$ & $\mathrm{a}$ & 9 & 4.7 & 3 & 2.9 & 11 & 7.3 \\
\hline N1 & $\mathrm{a}$ & 12 & 6.3 & 11 & 10.6 & 11 & 7.3 \\
\hline I & & 3 & 1.6 & 0 & 0 & 0 & 0 \\
\hline W & $\mathrm{a}$ & 6 & 3.1 & 1 & 1 & 4 & 2.7 \\
\hline $\mathrm{X}$ & & 1 & 0.5 & 2 & 1.9 & 0 & 0 \\
\hline $\mathrm{L} 1$ and L2 & $\mathrm{a}$ & 6 & 3.1 & 2 & 1.9 & 2 & 1.3 \\
\hline M & $\mathrm{a}$ & 2 & 1 & 2 & 1.9 & 0 & 0 \\
\hline Pre-HV & & 2 & 1 & 1 & 1 & 6 & 4 \\
\hline Others & & 2 & 1 & 1 & 1 & 5 & 3.3 \\
\hline
\end{tabular}

$\mathrm{HV}^{*}$ harbors the entire HV lineage, excluding the $\mathrm{H}$ haplogroup. To avoid small sample size, haplogroups were either grouped on the basis of phylogeny (ie, N1 and I, W and X) or added to 'others' (haplogroups M and Pre- 
HV). Different letters in the unplanned test column indicate significant contribution of a specific haplogroup to the overall heterogeneity. RU indicates Russia and the Ukraine.

\section{Discussion}

Perhaps no single group of American colonists came to symbolize the spirit, aspirations and moral character of the United States than the Pilgrim settlers at Plymouth (see e.g., Bureau of Military and Civic Achievement 1922). But there is a 'dark side' to the Pilgrim story.

Their arrival on the Mayflower, the Fortune and the Anne from 1620 to 1622 was used by early political commentators (see e.g., Bureau of Military and Civic Achievement 1922) to establish the primacy of British Christianity, especially Protestantism, in the United States. Most current supporters of the nationalist ideology of Nativism base their views on the widely taught and accepted notion that White, Anglo-Saxon, Protestants founded America and, therefore, their descendants deserve the right to primacy as citizens (see e.g., Archdeacon 1983; Bennett 1995). Within this view, religious and racial minorities are deemed to be weaker contributors to the success of the United States and, therefore, should not have the same standing as those descended from the earliest arrivals who 'fought for and built our nation'(Lichtman 2009).

What we hope to accomplish with this revisionist account of the Plymouth Colony's religious and ethnic origins is to correct the historical record and document the religious diversity of America's earliest European colonists.

Indeed, as the present DNA results evidence, some of these earliest settlers were not even European, they were Middle Eastern and Central Asian. Our hope is that the present research will call into question archaic notions of 'superiority' among different groups of American citizens and bring us all face-to-face with our very diverse origins as a country.

In closing, we offer an additional painting of the Mayflower Thanksgiving shown below. This one is featured on the Mayflower Society website. Here the central figure of the worshipper is again shown wearing a yarmulke. Perhaps the artist knew the truth.

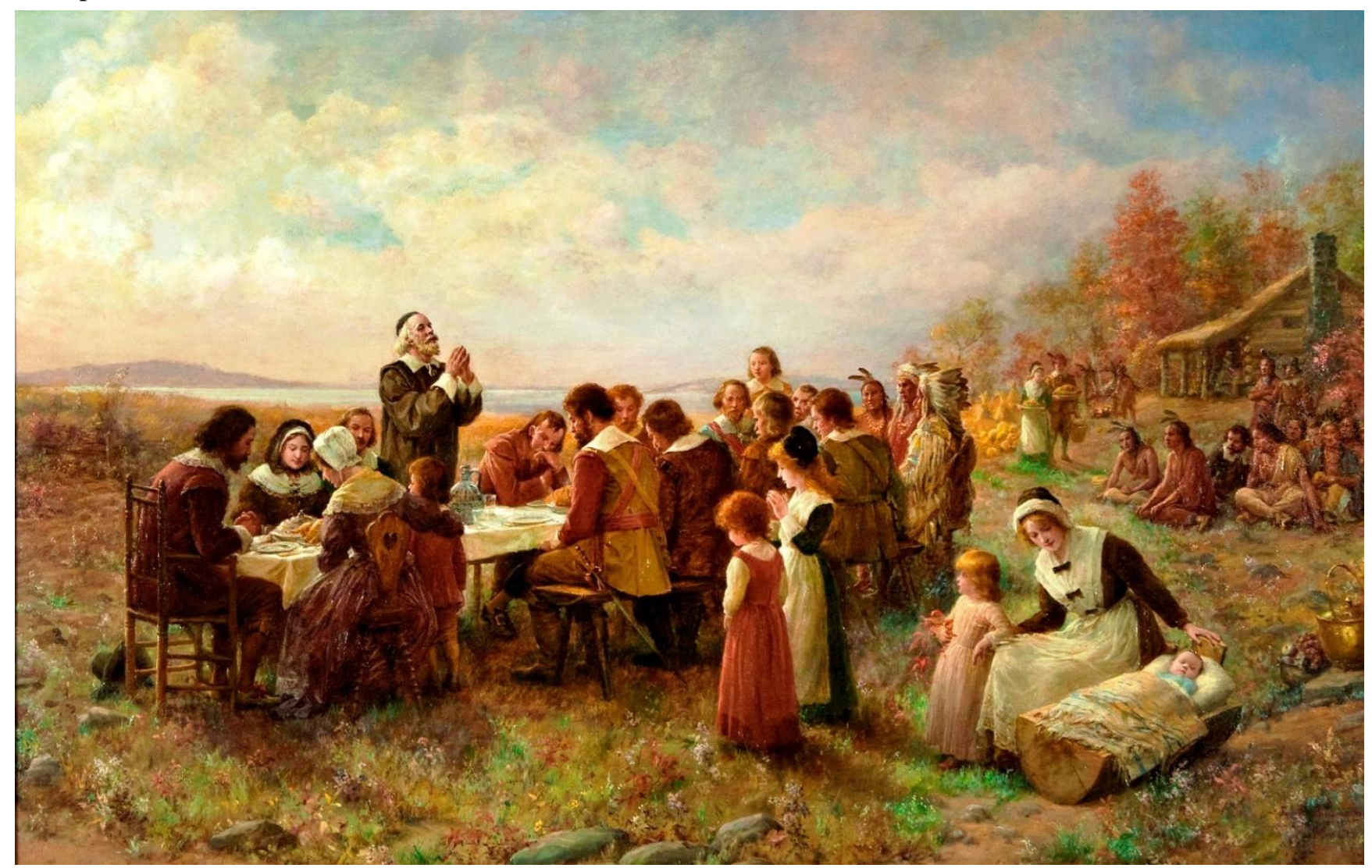




\section{References}

Abulafia, David (2011), The Great Sea: A Human History of the Mediterranean, Oxford,Oxford University Press. Archdeacon, Thomas J., (1983), Becoming American: An Ethnic History. New York.

Arredi B, Poloni ES, Paracchini S. et al. (August 2004). "A predominantly Neolithic origin forY-chromosomal DNA variation in North Africa”.American Journal of Genetics, 75 (2): 338-45. PMC 123160369

Aultman, Jennifer L. (2001). From Thanksgiving to War: Native Americans in Criminal Cases of Plymouth Colony 1630 - 1675.www.histarch.illinois.edu/plymouth/wampanoag.html

Bauchet, Marc; McEvoy, Brian; Pearson, Laurel N., Quillen, Ellen E., Sarkisian, Tamara, Hovhannesyan, Kristine; Deka, Ranjan; Bradley, Daniel G., Shriver, Mark D., (2007).Measuring European Population Stratification with Microarray Genotype Data. American Journal of Human Genetics. 80 (5): 948-956.

Behar, Doron M.; Ene Metspalu; Toomas Kivisild; Alessandro Achilli; Yarin Hadid; Shay Tzur; Luisa Pereira; Antonio Amorium; Llui's Quintana-Murci; Kari Majamaa; Corinna Herrnstadt; Neil Howell; Oleg Balanovsky; Ildus Kutuev; Andrey Pshenichnov; David Gurwitz; Batsheva Bonne-Tammir; Antonio Torroni; Richard Villems; Karl Skorecki (March 2006).The Matrilineal Ancestry of Ashkenazi Jewry: Portrait of a Recent Founder Event. The American Journal of Human Genetics. 78 (3): 487-497

Behar, DM; Thomas, MG; Skorecki, K; et al. (October 2003). "Multiple origins of Ashkenzai Levites: Y chromosome evidence for both Near Eastern and European ancestries".American Journal of Human Genetics, (73): 768-79.

Bennett, David H. (1995), The Party of Fear: From Nativist Movements to the New Right in American History. Rev. ed. New York.

Bodnar, John.(1985), The Transplanted: A History of Immigrants in Urban America. Bloomington, Ind.

Bradford, William. (1912), Of Plymouth Plantation. Massachusetts Historical Society. Boston.

Bradford, William and Edward Winslow (1622), The Mayflower Report, edited by David Bradford (2007-2008) Boston Hill Press.

Clifton E. Olmstead (1960). History of Religion in the United States, Englewood Clifts, N.J., Princeton.

Croxton, Derek. (1991). The Cabot Dilemma: John Cabot's 1497 Voyage \& the Limits of Historiography”, Essays in History, Corcoran Department of History at the University of Virginia.

Cruciani, Fulvio. et el. (2010), .Human Y chromosome Haplogroup R-V88: a paternal genetic record of early mid Holocenetrans-Saharan connections and the spread of Chadic languages:' European Journal of Human Genetics.3): 768-79.

Daniels, Roger.(1997), Not Like Us: Immigrants and Minorities in America, 1890-1924. Chicago.

Davis, David Brion, ed. (1970), The Fear of Conspiracy: Images of Un-American Subversion from the Revolution to the Present. Ithaca, N.Y.

DeConde, Alexander.(1992), Ethnicity, Race, and American Foreign Policy: A History. Northeastern: Boston.

Deetz, Patricia Scott and James F. Deetz. (2000). Passengers on the Mayflower: Ages \&Occupations, Origins \& Connectionswww.histarch.illinois.edu/plymouth/Maysource.html

Doenecke, Justus D.(2000), Storm on the Horizon: The Challenge to American Intervention, 1939-1941. Lanham, Md.

Donovan, Frank. (1968). The Mayflower Compact. New York: Grosset \& Dunlap.

Dumenil, Lynn. (1995), The Modern Temper: American Culture and Society in the 1920s. New York.

Edney, Matthew H. (n.d.), "The Cartographic Creation of New England". Osher Map Library and Smith Center for Cartographic Education, University of Southern Maine.

Fadhlaoui-Zid et al. (2015), Sousse: extreme genetic heterogeneity in North Africa. Journal Of Human Genetics (2015) 60, 41-49; doi 10.1038/jhg.2014.99; published online 4 December 2014

Fadhlaoui-Zid, K., Martinez-Cruz., Khodjet-el-khil., Mendizabal, I., Benammar-Elgaaied, A., and Comas, D. (2011), "Genetic structure of Tunisian ethnic groups revealed by paternallineages."American Journal of Physical Anthropology.

Gerard N., S. Berriche, A. Aouizerate, F. Dieterlen, G. Lucotte. (June 2006). "North African Berber and Arab influences in the western Mediterranean revealed by Y-chromosome DNA haplotypes". Human Biology; an International Record of Research.78 (3) 307-316.

Gwynne, Paul (2017). World Religions in Practice: A Comparative Introduction (2nd ed.). John Wiley \& Sons.

Leach, Douglas Edward. (September 1951). "The Military System of Plymouth Colony". The New England Quarterly. 24 (3): 342-364. 
Lewis, Richard (2011), Human Genetics: Concepts and Applications, Tenth edition, McGraw-Hill

Maxwell, Richard Howland (2003). "Pilgrim and Puritan: A Delicate Distinction". Pilgrim Society Note, Series Two. Pilgrim Hall Museum.

Moore, Jacob Bailey (1851). Lives of the Governors of New Plymouth and Massachusetts Bay. Boston: C. D. Strong. pp. 417-418.

National Geographic DNA Project. (2006). NationalGeographic.com

Olmstead, Clifton E. (1960), History of Religion in the United States, Prentice Hall, Englewood Cliffs, N.J.

Philbrick, Nathaniel, (2006), Mayflower, New York, Penguin.

Robino, C., Crobu, F., Di Gaetano, C., et al. (2008). "Analysis of Y-chromosomal SNP haplogroups and STR haplotypes in an Algerian population sample". International Journal of Medicine (3); 251-259.

Rootsi, Siiri; et al. (17 December 2013). "Phylogenetic applications of whole Y-chromosome Sequences and the Near Eastern origin of Ashkenazi Levites". Nature Communications.

Rothbard, Murray, (1975). The Founding of Plymouth Colony, Arlington House Publishers.

Taylor, Norris (1998)."The Massachusetts Bay Colony".(available on RootsWebFreePages)Timeline of Plymouth Colony 1620-1692 :www.plimoth.org//files/media/pdf

Users/Owner/Documents/FamilyTreeDNAAshkenazi-LeviteDNAProject(R1a1).

Users/Owner/Documents/FamilyTreeDNASephardicHeritageDNAProject.html.

Users/Owner/Documents/FamilyTreeDNATheJewishR1bProject.html.

Users/Owner/Documents/Haplogroup(Y-DNA), Eupedia.html.

Users/Owner/Documents/JewishDNAOmnibus.html.

Weisenthal, Simon. (1973). Sails of Hope: The Secret Mission of Christopher Columbus, New York: Macmillan 


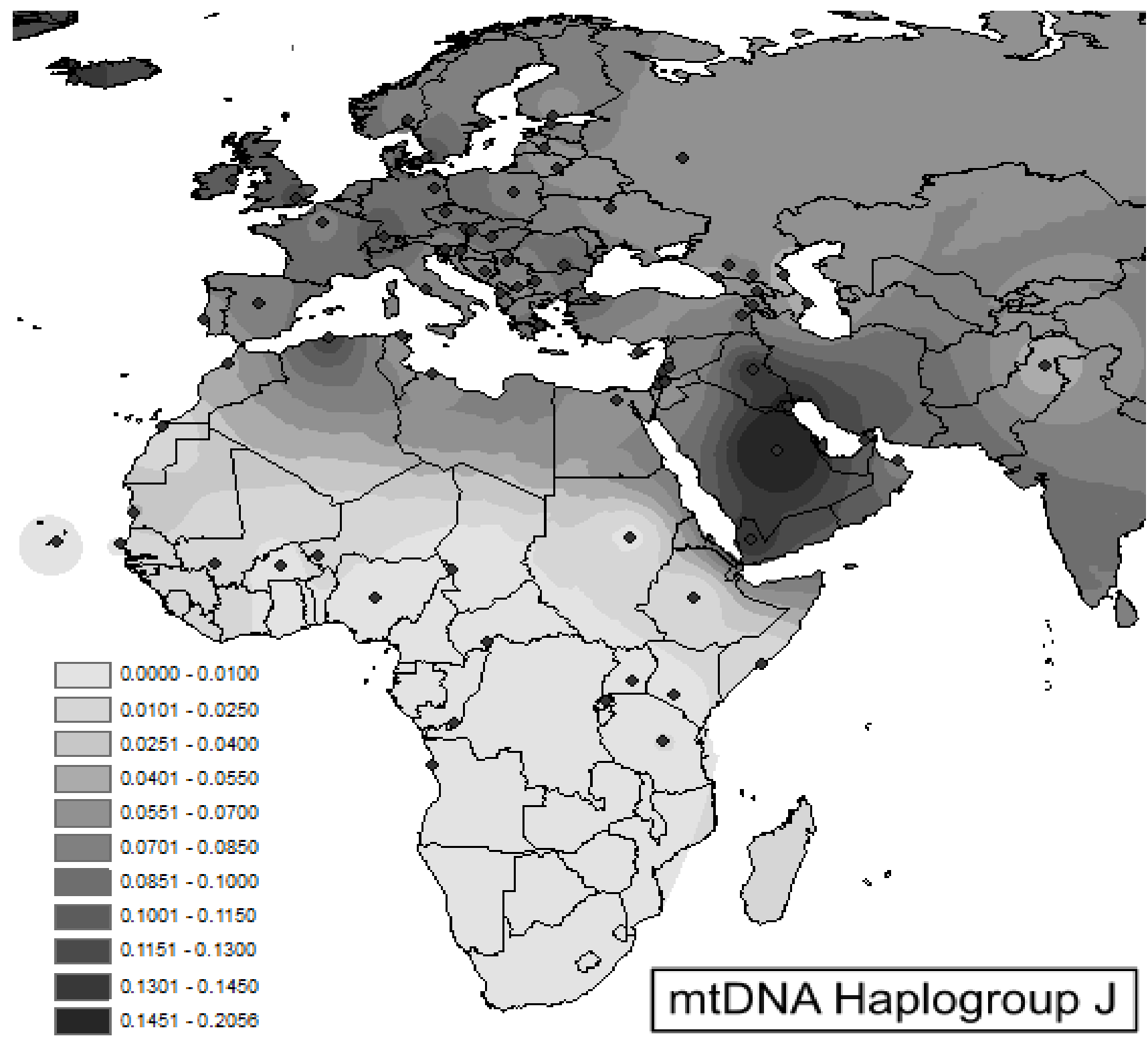




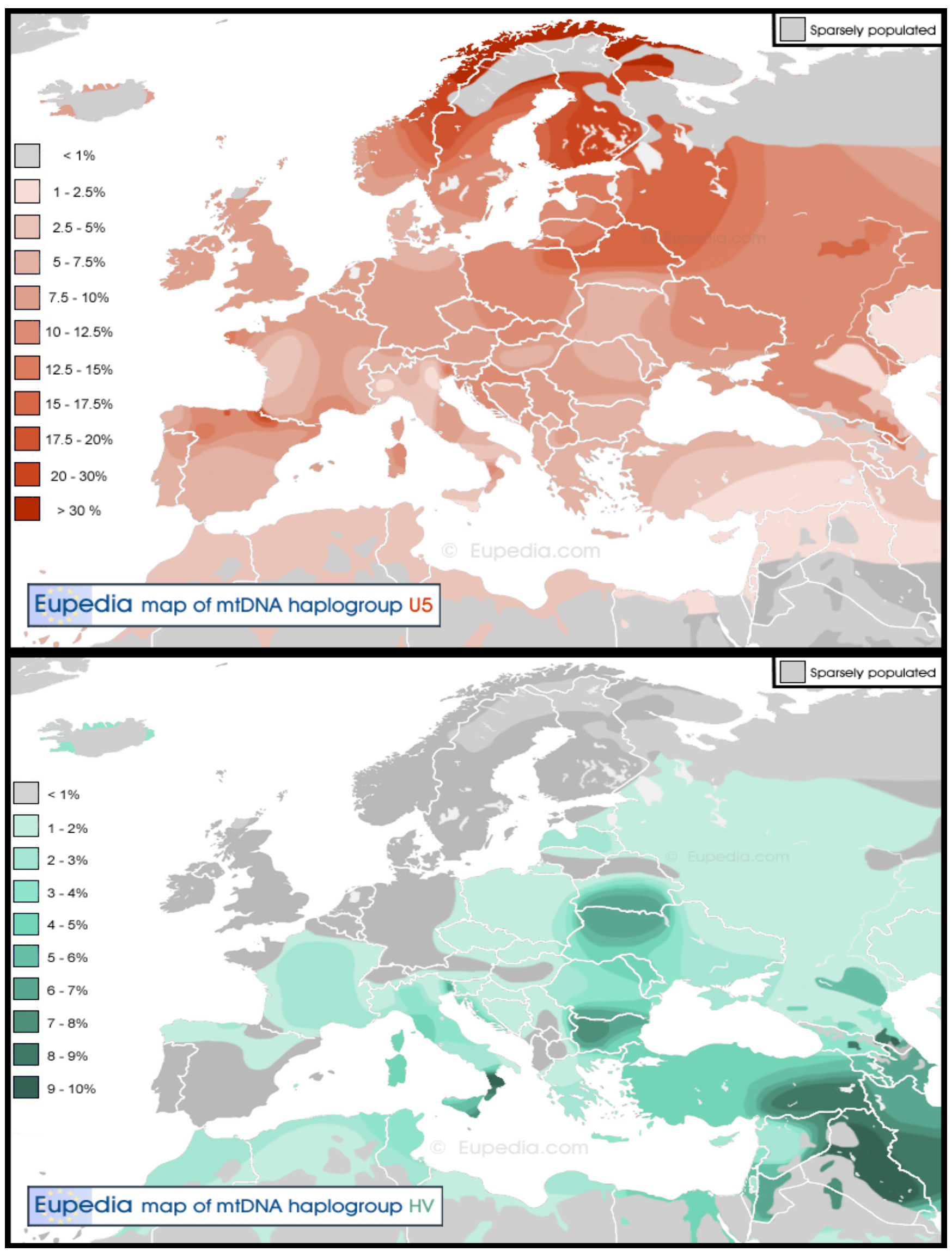



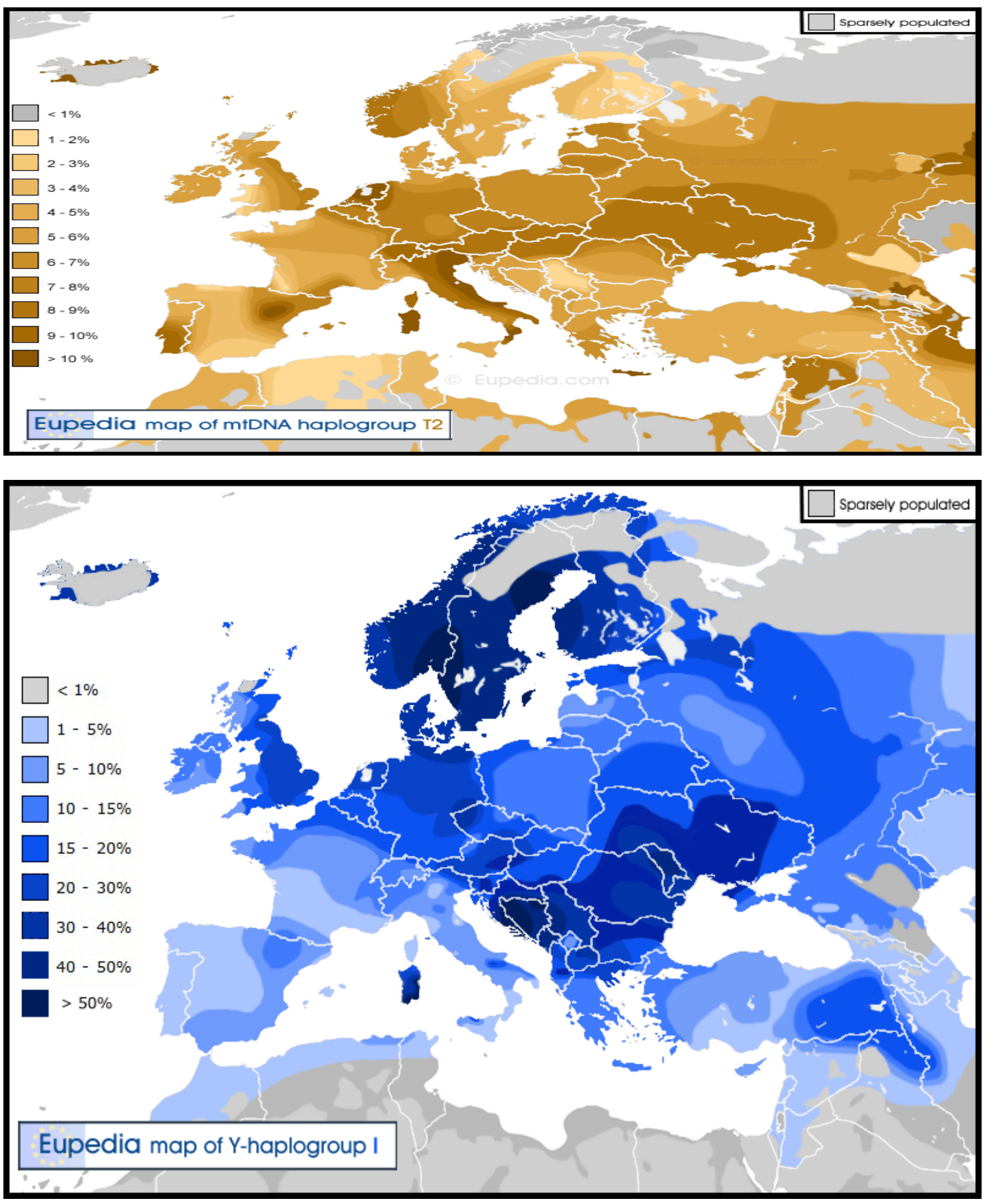